\title{
Bandage Dosage Form
}

National Cancer Institute

\section{Source}

National Cancer Institute. Bandage Dosage Form. NCI Thesaurus. Code C69012.

A solid composed of single or multilayered strips of permeable material. 